\title{
Investigating bilinguals' sensitivity to English regular past morphology: A self-paced reading experiment with Brazilian learners ${ }^{1}$
}

\author{
Investigação da sensibilidade de bilíngues \\ à morfologia regular de passado em inglês: \\ um experimento de leitura auto-cadenciada \\ com falantes brasileiros
}

Marisa Mendonça Carneiro*
Universidade Federal de Minas Gerais
Belo Horizonte, Minas Gerais / Brasil

\begin{abstract}
It is known that adult learners of English as an additional language (EAL) have difficulty in producing inflectional morphemes such as the third person present singular $-s$ and regular past $-e d$. One possible explanation is that bilinguals are not sensitive to inflectional morphemes, in comprehension tasks as evidenced by longer latencies at critical positions in reaction time experiments, when compared to native controls. Having the above in mind, the objective of this paper is to investigate if in fact Brazilian EAL bilinguals are sensitive to regular past morphology in a self-paced reading task. Sentences varied on the use or absence of inflectional morphemes. The statistical analysis showed that EAL speakers are not sensitive to past morphology. The results are discussed in light of Distributed Morphology and of previous studies on production and processing of inflectional morphemes in EAL.
\end{abstract}

KEYWORDS: Bilingual processing; self-paced reading; inflectional morphology; Distributed Morphology

RESUMO : É sabido que bilíngues do inglês como língua adicional (L2) têm dificuldade com a produção de morfemas flexionais, tais como $-s$ da terceira pessoa singular do presente, e -ed de passado regular. Uma possível explicação

\footnotetext{
${ }^{1}$ This study is part of a PhD Dissertation supervised by Dr. Ricardo de Souza and Dr. Maria Luiza Cunha Lima.
}

*marisaufmg@gmail.com 
estaria na insensibilidade dos aprendizes em relação à presença dos morfemas flexionais, mostrado por latências maiores em experimentos de tempo de reação, quando comparados a latências de nativos. Tendo isto em vista, o objetivo deste estudo é investigar se bilíngues brasileiros são sensíveis ao morfema de passado em um experimento de leitura auto-cadenciada. A análise estatística dos resultados mostrou que bilíngues não são sensíveis ao morfema de passado. Os resultados são discutidos à luz da teoria de Morfologia Distribuída e de estudos anteriores sobre produção e processamento morfológico na L2.

PALAVRAS-CHAVE: processamento bilíngue; leitura auto-cadenciada; morfologia flexional; Morfologia Distribuída.

\section{Introduction}

A major issue for second language researchers is the understanding of the processes involved in foreign/second language (henceforth L2) learning. Cognitively speaking, L2 learning can be described as changes in the mental representation of the target language in the learner's mind (SELINKER, 1972; JIANG, 2007). Such changes are observable through his/her performance in L2, and thus can be taken as evidence of learning, which means that new knowledge has been added or existing knowledge has been reorganized (JIANG, 2007). Nevertheless, L2 learners, unlike native speakers, eventually stabilize at some point in their grammatical development. In other words, even fluent L2 speakers show evidence of non-native performance or have 'fossilized' grammars (DOMINGUEZ, 2007; HAWKINS, 2000; LONG, 2003; SELINKER, 1972; WHITE, 2003).

A great deal of research has investigated morphological variability in the production of L2 learners. In fact, L2 learners exhibit variable use of inflectional morphology, such as tense and agreement (HAWKINS; LISZKA, 2003; LARDIERE, 1998; PRÉVOST; WHITE, 2000), as well as items associated with functional categories, such as auxiliaries and determiners (TRENKIC, 2007; WHITE, 2003; among others). It is interesting to note that such variability is pervasive throughout the course of acquisition and seems to be restricted to functional morphology. Hawkins (2000) refers to bilinguals' failure in the morphological domain as 'selective fossilization', while Sorace (2000) termed it 'syntactic optionality.'2 The

\footnotetext{
${ }^{2}$ Sorace (2000, p.93) defined the term as "the coexistence within an individual grammar of two or more variants of a given construction, which: (1) make use of the same lexical resources; and (2) express the same meaning." I will use the term 'morphological variability' to refer to the phenomenon defined by Sorace (2000).
} 
examples below illustrate verbal inflection-related variability, evidenced by the co-occurrence of finite and non-finite verbs in obligatory finite contexts, in the oral production of English L2 throughout different first language (L1) backgrounds:

(1) She give me a lot of help - L1 Chinese (LARDIERE, 1998).

(2) Sometimes he go out... to play with his friends - L1 Turkish (WHITE, 2003).

(3) Then my boss called the operation and the man tell him my telephone number and he told me I have to go to Rio on Monday... - L1 Brazilian Portuguese (CARNEIRO, 2008).

(4) But one day one beautiful princess arrived in a castle and talk with her parents... - L1 Brazilian Portuguese (CARNEIRO, 2008).

The high degree of variable use of inflection-related morphology observed in L2 learners' production has given rise to an ongoing debate which centers on the presence or absence of functional categories (Inflection or Tense) in the early stages of acquisition and on the properties these categories might have after they have been projected (RULE; MARSDEN, 2006; WHITE 2003). In recent second language acquisition (SLA) research, two different perspectives on L2 morphological problems have emerged. On the one hand, the Competence Deficit Approach posits that L2 learners' morphophonological difficulties are due to an impairment of the L2 grammatical system, particularly of certain properties of functional categories (FRANCESCHINA, 2001; HAWKINS, 2007). On the other hand, for the proponents of the Performance Deficit Approach, such difficulties are due to problems in accessing, retrieving, or controlling what has already been internalized. According to the Performance Deficit Approach, L2 learners have unconscious knowledge of the functional projections and feature values for Tense or Inflection, but they fail in the realization of surface morphology. For this reason, their morphophonological productions do not always coincide with target-like forms (HAZNEDAR, 2003; HERSCHENSOHN, 2001; PRÉVOST; WHITE, 2000). In summary, there is no agreement as what the source of the variability might be, that is, whether or not it is a reflex of grammatical deficit.

Nevertheless, both approaches do not take into account the role of online processing in second language performance (TOWEL, 2004), which 
is crucial for the successful acquisition of a language. In fact, the majority of SLA studies have been informed by performance data, which usually include production data (e.g. spontaneous speech, and experimentally elicited speech data), comprehension data, and grammaticality judgments (LAKSHMANAN; SELINKER, 2001; SATO; FELSER, 2007). Although L2 processing is believed to play a role in the acquisition of the L2 grammatical system, little is known about how language learners comprehend or produce language in real time (CLAHSEN; FELSER, 2006). As for the inflectional-related morphology, few studies have investigated learner's sensitivity to inflectional morphology in L2 processing (SATO; FELSER, 2007).

Despite the fact that there is growing evidence on how L1 speakers process language, little is known about how bilinguals produce and comprehend language. It is thus necessary to investigate the causes of inflectional variability in Brazilian Portuguese learners of English from a processing perspective. The hypothesis under investigation is that highly proficient non-native speakers of English are, much like native speakers, sensitive to violations of tense/agreement, as evidenced by significant differences between reading times of sentences in two conditions. If learners are insensitive to violations, knowledge of inflectional morphology is not automatically available, and learners will face problems acquiring it. This paper reports a first attempt to investigate whether Brazilian English as an additional language (EAL) learners are sensitive to regular past morphology in a self-paced reading task.

The structure of the paper is as follows. Section 2 highlights the importance of L2 processing studies in SLA research and the need for empirical evidence in order to account for acquisition. It also provides a background against which the present study is justified. Section 3 presents the objectives, hypothesis, and variables in the study, while section 4 describes the methodology that was used. Section 5 presents the results, and section 6 discusses these results.

\section{The role of processing in $\mathrm{L} 2$}

According to Towell (2004), the goal of second language researchers is two-fold: (i) explain how bilinguals manage to construct a mental representation of the target language to be acquired, which requires a conceptualization of linguistic structure (a property theory) and how such 
language structure is modified along the way (a transition theory); and (ii) explain how L2 learners are able to make use of this mental representation in order to comprehend or produce language, which requires a performance theory. The latter goal presupposes a conceptualization of how knowledge can be used to comprehend or produce language, that is, a performance or processing theory.

Likewise, Juffs (2004) advocates that a property theory and a transition theory are both necessary if second language researchers are to understand adult SLA. In addition, it has been argued that language processing is involved in both L1 and L2 acquisition (JUFFS, 2004). The author considers that processing is also part of a transition theory, and thus an understanding of L2 processing is central to constructing a theory of SLA. Even though processing plays a pivotal role in language acquisition, little is known about how input is processed in order to contribute to the development of new L2 representations. In fact, "too little is known about the formal details of how L2 learners process L2 input online, even when they already have some ability in the L2" (JUFFS, 2004, p. 200). Since one of the goals of SLA research is to understand how linguistic knowledge is mentally processed or accessed in the target language (a processing theory), psycholinguisticallyoriented research would have clear implications for the development of empirically-based models and theories of language acquisition.

To acquire an L2 successfully, linguistic input needs to be processed in real time (CLAHSEN; FELSER, 2006). In fact, an input string can only be assigned a grammatical structure if knowledge of the combinatorial rules and grammatical constraints of the target language is present. By the same token, grammatical knowledge requires appropriate input processing mechanisms in order to be built. In other words, there is no linguistic processing without knowledge of grammatical structure and vice-versa. The challenge for L1 and L2 theories is to investigate L2 learners' grammatical processing routines so as to add to the existing knowledge of bilinguals' grammatical development. Despite the fact that there is considerable evidence on L1 processing mechanisms, psycholinguistically-oriented research on L2 processing is still scarce.

Based on existing research which investigated L2 learners' mechanisms employed to process sentence-level and word-level information in real time, Clahsen and Felser identified distinct characteristics in the way monolingual speakers, child L1, and adult L2 learners process the target language. The 
first difference is related to difficulty L2 learners may have with the online integration of different information sources, that is, lexical, discourselevel, prosodic, and structural information. The second difference is the speed with which language learners process the target language, possibly reflecting a lack of automaticity, while the third difference is associated with L1 transfer of processing mechanisms. The fact that the language processing mechanisms which are fully available to mature L1 speakers may be only partially available to L2 learners is the final difference. The present study attempted to contribute with empirical evidence to account for the second difference, that is, the issue of automaticity. More specifically, the idea is to investigate whether or not Brazilian learners of L2 English process inflectional morphology automatically.

\subsection{Morphological sensitivity}

Native speakers of English have been shown to be sensitive to agreement violations, as evidenced by longer latencies at critical positions in a self-paced reading task. For instance, when reading sentences like (5a) and (5b), native speakers of English took significantly longer to read sentence (5b) than sentence (5a). The idea is that they may have noticed the number disagreement, leading to a delay in their reading of the word 'rusty' (PEARLMUT'TER et al., 1999, p. 429):

(5a) The key to the cabinet was rusty from many years of disuse.

(5b) * The key to the cabinet were rusty from many years of disuse.

The finding of such sensitivity in native speakers allows one to establish a link between learners' observable behavior (reaction times in reading) and their mental representations. In other words, a delay in reading ungrammatical sentences shows that the learner is sensitive to grammatical errors, which suggests that the activation of the related linguistic knowledge is automatic. Therefore, one can hypothesize that such linguistic knowledge has become integrated and automatized (JIANG, 2007).

Non-native speakers, on the other hand, may not be sensitive to inflectional morphology. Jiang $(2004,2007)$ tested Chinese EAL learners' sensitivity to the plural $-\mathrm{s}$ morpheme and subject-verb agreement in a series of self-paced word-by-word reading experiments. The non-native speakers failed to show a significant difference for the plural sentences in the two conditions (grammatical and ungrammatical) as shown in (5a) and (5b) 
(JIANG, 2007). The results suggest that EAL speakers may not be sensitive to the plural -s and subject-verb agreement, since there were no significant differences in the reading times for the two versions of the sentences, as opposed to native speakers. Following and extending Jiang's methodology, this study is an attempt to determine whether Brazilian EAL learners are sensitive to the regular past morpheme.

\subsection{Brazilian Portuguese}

Brazilian Portuguese (henceforth BP) is a language with rich agreement morphology (RAPOSO, 1992), as opposed to Chinese. An example can be seen in the past tense paradigm of the verb 'trabalhar' (to work), compared to its English translation:

(6) Past tense paradigm of BP

$\begin{array}{ll}\text { Eu trabalhei } & \text { Nós trabalhamos } \\ \text { Tu trabalhaste } & \text { Vós trabalhastes } \\ \text { Ele/a trabalhou } & \text { Eles/as trabalharam. }\end{array}$

I worked We worked

You worked You worked

He/she worked They worked.

As shown by Biberauer and Roberts (2008), the difference between Germanic and Romance languages lies in the richness of the inflectional marking of tense distinctions. Romance languages are considerably richer, as shown in (7) (BIBERAUER; ROBERTS, 2008, p. 26):

(7) Inflectional paradigm of Romance and Germanic languages

\section{Romance:}

French: parle (present indicative/subjunctive), parlerai (future), parlerais (conditional), parlais (imperfect), [parlai (preterit), parlasse (past subjunctive)]

Italian: parlo (present), parlerò (future), parlerei (conditional), parlavo (imperfect), parli (present subjunctive), parlassi (past subjunctive)

Spanish: hablo (present), hablarò (future), hablarei (conditional), bablaba (imperfect), bablé (preterit), hable (present subjunctive), hablase (past subjunctive I), hablara (past subjunctive II) 


\section{Germanic:}

German: spreche (present indicative/subjunctive), sprach (past), spräche (past subjunctive)

English: speak (present), spoke (past)

Swedish: snakker (present), snakket (past)

However, as shown by a well-documented erosion process of this rich morphological paradigm, inherited by European Portuguese, BP is reorganizing its pronominal system, leading to a reduction of the verbal paradigm. Such a reduction is a direct consequence of an increasing proportion of overt pronominal subjects from the 19th to the 20th century (CAMACHO, 2012). In fact, Kato (2002) argues that BP can now be considered a partial pro-drop language, licensing null subjects in third person, but not in first and second person. The verbal paradigm is now marked by three distinct endings: one for 'speaker sg.', one for 'hearer sg.', 'other sg.' and 'speaker pl.', and one for 'addressee.pl', and 'other pl.' Camacho also highlights that the same happened in some Caribbean varieties of Spanish. Still, BP is a language with richer inflectional tense marking when compared to English. It is plausible to suppose that Brazilian learners of English would be sensitive to inflectional markings in their own native language and would not have problems acquiring this feature in the L2.

Assuming that production and comprehension systems access shared grammatical representations, we hypothesize that if EAL learners are insensitive to inflectional morphemes, as evidenced by similar reading times when reading grammatical and ungrammatical sentences, they will have difficulty acquiring the correct feature specification of the related functional categories associated with these morphemes. This difficulty may lead to underspecified or non-target-like grammatical representations (SATO; FELSER, 2007). It is also hypothesized that learners' sensitivity to inflectional morphemes is dependent upon the proficiency level. In other words, the more proficient the learner is, the higher the sensitivity to inflectional morphemes.

\subsection{Distributed Morphology}

The idea of feature and feature specification of inflectional morphemes can be accounted for when one assumes the architecture of language faculty as proposed in Distributed Morphology (HALLE; 
MARANTZ, 1993). For such a theory, the assignment of phonological features to morphosyntactic feature bundles occurs after the syntax, which means that phonological features do not create or determine the terminal elements. The terminal nodes consist exclusively of morphosyntactic/ semantic features and lack phonological features. Stems and affixes are called 'Vocabulary', which connects morphosyntactic feature bundles with phonological feature complexes. It is only after syntax that the phonological content, or Vocabulary Items, are inserted, in a process called Spell-Out. According to Halle and Marantz (1993, p.123):

Vocabulary can be regarded as the repository of the knowledge speakers have about the interrelationship between the morphosyntactic feature bundle characterizing a morpheme $e^{3}$ and its phonological features, that is, about the mapping of morphosyntactic features onto complexes of phonological features.

Vocabulary insertion is the process by which phonetic features are supplied to the different morphemes, i.e. terminal elements, which have been previously created by syntax. Nevertheless, the phonetic features may be underspecified in relation to the morphosyntactic feature complexes they realize, carrying only those features that determine which morpheme is inserted at which terminal node. For this reason, Vocabulary items are default signals in many cases, inserted where no more specific form is available (HALLE; MARANTZ, 1993; HARLEY; NOYER, 1999). As an example, the English past participle ending /-d/ in I had played tennis all day corresponds only to the feature [+past] in its Vocabulary entry, even though it was inserted into a node with the features [+ participle] and [+ past]. Since Vocabulary items may be underspecified in terms of feature content, they compete for insertion, being subject to the Subset Principle, according to which:

The phonological exponent of a Vocabulary Item is inserted into a morpheme if the item matches all or a subset of the grammatical features specified in the terminal morpheme. Insertion does not take place if the Vocabulary Item contains features not present in the morpheme. Where several Vocabulary Items meet the conditions for insertion, the item matching the greatest number of features specified in the terminal morpheme must be chosen. (HARLEY; NOYER, 1999, p.5).

\footnotetext{
${ }^{3}$ Morpheme' is used in Halle and Marantz (1993) to refer to terminal node elements both before and after Vocabulary insertion.
} 
Harley and Noyer (1999) highlight that the phonological content of a Vocabulary item may be any phonological sequence, including zero or $\varnothing$. In addition, the feature content or terminal node may not carry information, which yields a default Vocabulary item. However, zero and default items do not always coincide. As an example, the zero plural affix of certain marked nouns in English (e.g. sheep) does not coincide with the default plural form.

In addition, several moprhosyntactic features may be expressed by a single morpheme. This property, known as syncretism, can be seen in the verbal inflection paradigm of English. Past and present tenses present the following configuration:

(8) Inflectional paradigm of Present and Past tense in English

\begin{tabular}{c|c}
\hline \multicolumn{2}{c}{ Present } \\
\hline Singular & Plural \\
\hline 1. like & 1. like \\
\hline 2. like & 2. like \\
\hline 3. like-s & 3. like \\
\hline
\end{tabular}

\begin{tabular}{c|c}
\hline \multicolumn{2}{c}{ Past } \\
\hline Singular & Plural \\
\hline 1. like-d & 1. like-d \\
\hline 2. like-d & 2. like-d \\
\hline 3. like-d & 3. like-d \\
\hline
\end{tabular}

The verb like, in the third person singular, is specified for person [+3], number $[+$ singular $]$ and tense $[+$ present], while the other verb forms are underspecified for person and number, and specified for tense [+ present]. The ungrammaticality of 'he like Mary' is evidence that the third person singular is a more specified form and that the Subset Principle ruled out the choice of a less specified form when a more specified one is available. Hence, the feature configuration for verbal inflection in English is the following (HARLEY; NOYER, 1999):

(9) Feature configuration for Present and Past tense in English

Like-s $[+3,+$ singular, + present $]$

Like $[+$ present $]$

Like-d [+ past] 
Distributed Morphology is a grammar model that separates the mechanisms that generate a syntactically complex expression from the mechanisms that supply the corresponding phonological expression. For this reason, it is a model that could account for problems with language comprehension and production (PFAU, 2009). We assume that the architecture of the language faculty is what determines the organization of grammar in human beings, native and non-native speakers of a language alike. We also take the ideas presented in Distributed Morphology as a starting point in the analysis of the processing data elicited by the self-paced reading task.

\section{The study}

\subsection{Objective}

The objective of this research is to determine whether Brazilian EAL learners are sensitive to the regular past morpheme in a self-paced reading experiment. Their sensitivity was measured in terms of their reading times of sentences presented under different conditions, as compared to the reading times of English native speakers.

\subsection{Hypotheses}

If non-native speakers are sensitive to regular past morphology, there will be a statistically significant difference when the reading times of grammatical and ungrammatical sentences are compared, similar to native speakers. Moreover, more proficient non-native speakers are expected to show significant differences in their reading times of sentences under different conditions, as opposed to less proficient non-native speakers.

\subsection{Variables}

The independent variables in this research are the spoken languages (English natives vs. non-native English speakers), proficiency level, and grammatical and ungrammatical sentences. The dependent variable is the reaction time at critical positions. 


\section{Method}

\subsection{Participants}

A total of 27 bilinguals from two proficiency levels ${ }^{4}$ (15 were high proficiency and 12 were low proficiency) took part in the experiment. These learners are native speakers of Brazilian Portuguese and live in an environment in which English is a foreign language. The participants were mostly young, all of which had a university degree, as shown by Table 1 .

TABLE 1 - Profile of non-native speakers (\%).

\begin{tabular}{c|c|c|c|c|c|c|c|c|c}
\hline \multicolumn{7}{c}{ Non-native speakers (n = 25) } \\
\hline \multicolumn{2}{c|}{ Gender } & \multicolumn{7}{c}{ Age group } & \multicolumn{2}{c}{ Schooling } & \multicolumn{2}{c}{ Proficiency } \\
\hline F & M & $\begin{array}{c}18 \text { to } \\
29\end{array}$ & $\begin{array}{c}30 \text { to } \\
39\end{array}$ & $\begin{array}{c}40 \text { to } \\
44\end{array}$ & $\begin{array}{c}65 \text { to } \\
69\end{array}$ & undergraduate & graduate & high & low \\
\hline 44.0 & 56.0 & 60.0 & 28.0 & 8.0 & 4.0 & 56.0 & 44.0 & 52.0 & 48.0 \\
\hline
\end{tabular}

The control group consisted of 13 native speakers of English. Most of these ( 8 individuals) were males, either British or American, and had been living in Brazil for less than one year (Table 2):

TABLE 2 - Profile of native speakers ( $\%)$

\begin{tabular}{c|c|c|c|c|c|c|c|c}
\hline \multicolumn{7}{c}{ Native speakers ( $\mathrm{n}=13)$} \\
\hline \multicolumn{2}{c|}{ Gender } & \multicolumn{5}{c|}{ Nationality } & \multicolumn{3}{c}{ Time of residence in Brazil } \\
\hline F & M & Barbadian & Australian & British & American & $>1$ year & $\begin{array}{r}1 \text { to } \\
4 \text { years }\end{array}$ & $\begin{array}{r}18 \text { to } \\
19 \text { years }\end{array}$ \\
\hline 31.0 & 69.0 & 7.6 & 7.6 & 38.7 & 46.1 & 53.8 & 30.7 & 15.3 \\
\hline
\end{tabular}

\subsection{Stimuli}

A self-paced reading experiment was conducted to investigate EAL learners' sensitivity to past inflectional morphology. DMDX was used to present stimuli and collect reaction time data. The test materials for the past

\footnotetext{
${ }^{4}$ Learners were placed in the high or low proficiency group according to their score in the Placement Test from The Oxford University Language Centre. Those who were placed in A2 and B1 levels were considered low proficiency and those placed in B2, C1, and C2 levels were considered high proficiency learners.
} 
experiment consisted of regular verbs embedded in sentences. The target verbs were matched for frequency and length, based on the list presented in Morris and Holcomb (2005), as well as from the 'top 5000 words / lemma' list, from the Corpus of Contemporary American English. ${ }^{5}$ The sentences were presented in two conditions: grammatical, i.e. target verb correctly inflected for past, and ungrammatical, i.e. target verb not inflected for past. All target sentences started with a dependent clause, comprised of an adverb (when, while, after, or because), followed by a definite NP, a regular intransitive verb in the past and an adjunct. The objective of this first clause was to create a past context. After that, an independent clause was introduced, starting with a definite NP, followed by a VP containing a 4 letter-monosyllabic regular verb, a 3-syllable definite NP, and a 4-syllable adjunct. This pattern was present in all target sentences. A sample sentence can be seen in (10):

(10)

\begin{tabular}{c|c|c|c|c|c|c|c}
\hline 1 & 2 & 3 & 4 & 5 & 6 & 7 & 8 \\
\hline Adverb & definiteNP & $\begin{array}{c}\text { Regular } \\
\text { intrans. verb }\end{array}$ & adjunct & definiteNP & $\begin{array}{c}\text { 4-letter } \\
\text { reg. verb }\end{array}$ & 3-syllableNP & $\begin{array}{c}\text { 4-syllable } \\
\text { adjunct }\end{array}$ \\
\hline After & the rain & started & at last & the farmer & picked & the flowers & $\begin{array}{c}\text { from the } \\
\text { garden. }\end{array}$ \\
\hline
\end{tabular}

The last three segments (target verb, 3-syllable definite NP, and the 4-syllable adjunct) are matched for frequency, with words taken form the 'top 5000 words/lemma' list, from the Corpus of Contemporary American English. The objective is to avoid bias related to word frequency. Reaction times were measured in the last three positions. The following examples illustrate the test sentences in the two conditions:

(11) Grammatical version:

Because/ the dog/ barked/ ferociously/, the mailman/ pushed/ the letter/ under the door.

(12) Ungrammatical version:

* Because/ the dog/barked/ ferociously/, the mailman/push/ the letter/ under the door.

\footnotetext{
${ }^{5}$ Available at <http://www.americancorpus.org/>.
} 
The only difference between the two versions is related to the use and absence of the regular past morpheme. To determine participants' sensitivity to past morphology, their reading times in the last three positions of the grammatical and ungrammatical version were compared. The reading times of the control group were also compared. If a significant difference was observed in the reading times of sentences under the two conditions, then it could be said that the participant was sensitive to regular past morphology. It then follows that if participants were sensitive to the ungrammaticality in (12), they were expected to show a longer latency following this position when compared to the reading of the grammatical version. Since the delay may not be perceived until the next word or two, the second and third positions following the target verb were of particular interest. This phenomenon is described in the literature as the 'spillover effect' (MITCHELL, 2004).

A total of 40 test sentences were constructed for this experiment. Sentences were randomized and presented under the two conditions: 20 grammatical sentences and 20 ungrammatical sentences. Half of the sentences in each condition were followed by a comprehension question. Out of the sentences followed by questions, half required a positive answer and the other half required a negative answer.

In addition to the test sentences, 80 filler sentences were also part of the experimental sentences. These sentences, which were all well-formed, were taken from the sentences used in Osterhout and Mobley (1995). Half of the filler sentences were followed by a comprehension question. Half of these questions required a positive answer, while the other half required a negative answer. Thus, a total of 120 sentences were read by the participants. An example of a filler sentence can be seen in (13):

(13) African elephants/ live/ in the jungle.

To ensure that each participant only saw one member of each (grammatical-ungrammatical) pair, the test items were distributed across two presentation lists in such a way that each list contained equal numbers of items from all conditions but only one member of each pair. The test items and fillers in each list were pseudo-randomized, yielding a total of 120 stimuli per presentation list. 


\subsection{Procedures}

Participants were first asked to give informed consent. ${ }^{6}$ Non-native learners were then asked to take the placement test and answer questions about their language background, age, and schooling. Native speakers of English had only to answer questions related to their time of residence in Brazil and language background. Following that, participants did the reading task. Written instructions were displayed, and five practice items were given before the experimental sentences were shown. The instructions asked participants to read sentences for comprehension. No feedback was provided as to the accuracy of comprehension questions. Sentences were read following the moving window condition (MITCHELL, 2004), as illustrated in (14):

(14) moving window presentation

After

----- the fire stopped

completely

-the firefighter

A 10" notebook was used to run the experiment, with a joystick as an input device. To read sentences and answer yes/no to comprehension questions, participants had to push a designated button on the joystick. The presentation of the stimuli and the recording of response times were controlled by DMDX. After data collection, statistical analyses were carried out to test the hypothesis. Participants took 25 to 40 minutes to complete the experiment.

\section{Results}

Reaction times at the three critical positions described in the previous section were analyzed. These positions correspond to the regular verb, 3-syllable NP, and the 4- syllable adjunct. To test the hypothesis, the Generalized Estimating Equations (GEE) was used as the statistical model.

\footnotetext{
${ }^{6}$ Approval number CAAE - 0419.0.203.000-09.
} 
The GEE is an adequate model to the analysis of correlated data, such as a within-subjects design, since it does not presuppose a normal distribution of data (FITZMAURICE et al., 2004). Two models were proposed: one that compared native speakers with EAL learners and another that compared the two groups of bilinguals. The results are presented for each position. Significance level was determined at $\mathrm{p}<0.05$.

\subsection{4-letter regular verb}

The comparison between native $(n=13)$ and non-native speakers $(n=25)$ resulted in no statistical differences for the reading times of both groups ( $p=0.128 ; \mathrm{SE}=61.6)$ and for sentence condition $(\mathrm{p}=0.531 ; \mathrm{SE}=16.8)$.

As for the comparison between the bilinguals' groups, no statistically significant difference was found $(\mathrm{p}=0.24 ; \mathrm{SE}=46.7)$. The grammaticality of the sentence presented a marginal difference when low $(\mathrm{n}=12)$ and high proficiency $(n=15)$ groups are compared $(\mathrm{p}=0.072 ; \mathrm{SE}=17.5)$.

\subsection{3-syllable NP}

The 3-syllable NP revealed a significant difference between native speakers and bilinguals in relation to reading times $(p=0.003 ; \mathrm{SE}=59.3)$, with bilinguals taking longer to read sentences at this point. Native speakers took, on average, 47.6 milliseconds longer to read sentences in the ungrammatical conditional, when compared to the grammatical ones. This difference was statistically significant $(\mathrm{p}=0.007 ; \mathrm{SE}=17.6)$. The bilingual group did not show any difference related to sentence condition $(p=0.15 ; \mathrm{SE}=18.7)$ among the non-native speakers.

\subsection{4-syllable adjunct}

Table 7 shows the statistical analysis for the 4-syllable adjunct position. There was only a marginal difference in the reading times between the native and bilingual groups $(\mathrm{p}=0.055 ; \mathrm{SE}=120.7)$ and for sentence condition ( $\mathrm{p}=0.096 ; \mathrm{SE}=22.7)$. The average reading time in the grammatical condition is 37.8 milliseconds higher than the average reading time in the ungrammatical condition.

The bilinguals did not differ in the reading times ( $p=0.095 ; \mathrm{SE}=116.8)$. Sentence condition did not significantly affect the reading times of the nonnative groups $(\mathrm{p}=0.75 ; \mathrm{SE}=22.7)$. 
The statistical analysis showed a significant effect of sentence condition on the reading times of the native speaker group. The average reading time of sentences in the grammatical condition was 47.6 milliseconds higher than the average reading time in the ungrammatical condition. However, sentence condition did not affect the reading times of non-native speakers. They also took significantly longer to read the segment presented in the 3-syllable NP when compared to the native speaker group. There was no statistically significant difference for the reading times between the low and high proficiency groups.

Native speakers showed greater variation in the reading times of sentences in the grammatical condition. For both non-native groups, there was little variation regarding sentence condition. In general, variation was consistent in the three groups, showing greater dispersion in the 4-syllable adjunct, which corresponds to the end of the sentence. Natives were faster than non-natives in all three positions.

\section{Discussion}

The present study was, to the best of our knowledge, the first to investigate adult Brazilian Portuguese EAL learners' sensitivity to regular past morphology. The sensitivity to regular past morphology was determined by testing whether bilinguals were sensitive to the ungrammatical wording caused by a missing morpheme, as shown by longer reaction times in a self-paced reading experiment. The hypothesis to be tested was that high proficiency bilinguals would be sensitive to the regular past morpheme, in a similar manner as that produced by native English speakers. The findings of this study showed that Brazilian EAL learners, as opposed to native speakers of English, were not sensitive to the absence of regular past morphemes. In other words, the study hypothesis was not confirmed.

The results showed statistically significant differences for the reading times in the two sentence conditions (i.e. grammatical and ungrammatical) in the native speakers group. Non-native speakers, on the other hand, did not present statistically significant differences, which may suggest that they are not sensitive to the regular past English morpheme. The longer reading time was found at position 7 , which corresponds to the NP following the target verb. This fact suggests that there was a spillover effect (MITCHELL, 2004).

If non-native speakers are insensitive to the regular past morpheme, then the implicit knowledge related to the need of tense marking may be 
incomplete or absent. Nevertheless, if non-native speakers did not have this knowledge represented in some way, they would not exhibit an accurate, though variable, use of inflectional verbal morphology (HAZNEDAR, 2003; LARDIERE, 1998; McCARTHY, 2004; PRÉVOST; WHITE, 2000; among others). In addition, as argued by Rothman (2007), if the variable use of inflectional morphology was a reflex of an impaired syntax, there would be an effect in the syntactic properties related to functional categories T/I or related semantic effects. As has been shown by several other studies, such effects have not been described.

Halle and Marantz (1993) argued that the Vocabulary is a repository of the knowledge speakers have about the interrelationship between the morphosyntactic features and its phonological realization. In other words, speakers have knowledge on the mapping between syntactic and phonological features. The non-native speaker needs to acquire these mappings in the target language, that is, he or she needs to notice in the input which Vocabulary items are mapped onto a bundle of syntactic features. However, mappings do not always coincide among languages, which pose a challenge to the second language acquisition process. Incomplete or deficient acquisition of the feature bundles that are part of Vocabulary items may be responsible for surface forms that are non-target. The analysis of deviant forms related to tense, gender, and number agreement in production and comprehension has shown that non-native speakers have difficulty in acquiring the phonological features that realize abstract morphemes (McCARTHY, 2008; PRÉVOST; WHITE, 2000; WHITE et al., 2004). This assertion is in accordance with Slabakova (2009), who claims that functional morphology is the 'bottleneck' of second language acquisition.

In addition to the lack of semantic effects associated with functional categories, the idea that problems with production and comprehension of functional items is restricted to Vocabulary items is corroborated by the presence of target forms, as well as by the absence of more specified forms in less specified terminal nodes. In fact, several studies have shown that learners make use of Vocabulary items whose features are compatible with the features of the terminal nodes, thus avoiding the insertion of Vocabulary items whose features are distinct from the features of terminal nodes (McCARTHY, 2006, 2008; PRÉVOST; WHITE, 2000; WHITE et al., 2004; XAVIER, 2008). This suggests that learners may be following the Subset Principle. It should be noted that such studies do not take into account processing issues, but they show non-native speakers linguistic behavior in 
spontaneous and elicited production, as well as in grammaticality judgment tasks, which assess mainly learners' explicit knowledge.

Such findings seem to corroborate the postulation that there is a separation between syntax and morphological instantiation. In fact, Distributed Morphology separates phonological instantiation from syntax, suggesting that the mechanisms that create syntactic expressions are distinct from the mechanisms that provide phonological material to the output of syntax. Phonological features are inserted at a later point in the derivation through Vocabulary insertion. This is to say that there is a separation between the Lexicon and syntax, or, that items that enter into the derivation do not carry phonological features. These features are not fully specified, that is, they may be underspecified for tense and gender, for example. Vocabulary insertion is subject to the Subset Principle, generating the correct phonologic content to the syntactic expression.

If we assume such a separation, we may postulate that the bilingual language architecture contains Vocabulary items that are not fully specified and that bilinguals may resort to a default item, though respecting feature specifications by avoiding feature clashes. We may also suggest that bilinguals would have separate Vocabulary items that would need to be learned, which runs in line with that proposed by MacSwan (2000). In other words, learners would need to learn the mappings between abstract syntactic features and their phonological instantiation. For this author, who adopts a Minimalist account for the bilingual language architecture, there should be two distinct Lexicons and two phonological components, one for each language. Languages would share the computational mechanisms. Such a proposal accounts for the occurrence of code-switching and code-blending, as shown in a study conducted by Lillo-Martin et al. (2010), in which the development of sign and spoken languages was investigated. MacSwan (2000) also presents data from code-switching between Spanish and Nahuatl, in which a first and second person pronoun in Spanish does not occur with a first or second person inflected verb in Nahuatl, but does occur with third person pronoun in Spanish and a third person inflected verb in Nahuatl. The author suggests that there is no conflict of features when person and tense features are checked in T. Thus, when there is a conflict in the feature matrices of Spanish subject pronouns and Nahuatl verbs, ungrammaticality will result. The data also suggest that bilinguals avoid feature clashes by allowing a third person form, which is usually not specified for person, to code-switch with 
a third person inflected verb. In other words, vocabulary items which are less specified in terms of the features they carry may code-switch and be used as defaults.

Processing studies investigating functional morphology have shown that non-native speakers are not always sensitive to agreement violations (BOND et al., 2010; JIANG, 2007; SAGARRA; HERSCHENSOHN, 2011). If learners are insensitive to verbal inflectional morphology, we could hypothesize that they will have difficulty acquiring the feature bundle of Vocabulary items that instantiate verbal inflection. Learners would then have a Vocabulary item with incomplete, probably underspecified features, and would depend on formal instruction to acquire explicit knowledge of which Vocabulary items instantiate inflection. We cannot state, however, if learners will reach a stage in which implicit knowledge of verbal inflection is present.

The choice of an underspecified Vocabulary item in interlanguage grammars is corroborated by studies that examined functional morphology in production and comprehension (McCARTHY, 2006, 2008; WHITE et al., 2004; XAVIER, 2008). These studies argue that learners make use of forms that have underspecified features. According to the feature geometry proposed by Harley and Ritter (2002), underspecified forms correspond to less marked ones. Thus, forms that contain singular, third person, masculine or present features are potentially default. This accounts for the fact that feminine forms are not found in a masculine context, plural forms are not found in a singular context, past forms are not found in a present context, and first and second person forms are not found in a third person context.

Learners seem also to have a fully specified Vocabulary item for verbal inflection, since variability in production data has evidenced the co-existence of fully specified and underspecified forms. If two feature configurations for the same Vocabulary item do exist, what drives the choice between them? Hawkins and Lisza (2003) suggested that the interlanguage grammar allows for the co-existence of two Vocabulary items - one that is more specified, and another, less specified. There would be no competition, a property of the Subset Principle, in which a more specified item would win the competition and be inserted in the terminal node. If competition is absent, then the two forms would be inserted at random, resulting in a $50 \%$ rate of use for each of them; that is, learners would produce target forms $50 \%$ of the time. However, this prediction is not confirmed by production studies. 
Carneiro (2008), Ionin and Wexler (2002), Lardiere (1998), Prévost and White (2000), White (2003), among others have shown that the incidence of overt past morphology in obligatory contexts ranged from $25 \%$ to $76 \%$. Carneiro (2008) also showed that the incidence of overt past morphology increased with proficiency, from $49 \%$ to $79 \%$ in obligatory contexts.

A possible explanation for variability, assuming that interlanguage grammars allow the co-existence of two Vocabulary items for inflectional verbal morphology is that learners make use of explicit knowledge when producing target forms, while underspecified forms are produced when access to explicit knowledge is not possible. Even though this is a plausible explanation, it does not make predictions on the observed stages that learners go through in the acquisition of inflectional morphology. This explanation also assumes that learners will reach a stage in which they exhibit implicit knowledge, reflected by their sensitivity to inflectional violations.

It is plausible to predict that learners will reach a stage in which they present implicit knowledge, based on evidence from studies involving self-paced reading and eye-tracking, as well as from neuroimaging studies. Self-paced reading studies suggest that non-natives are sensitive to gender and number agreement violations (BOND et al., 2010; SAGARRA; HERSCHENSOHN, 2011), while neuroimaging studies present evidence suggesting that more proficient non-native speakers activate the same brain areas that native speakers do (ABUTALEBI et al., 2005; LEONARD et al., 2011). These data corroborate the idea that bilingual processing is characterized by automaticity, reflecting implicit knowledge of the target language.

Further studies should investigate whether the same pattern of results is found when different methods are applied, such as eye-tracking. Since English is a language with poor morphological inflection, it would also be interesting to investigate the use of default morphology in languages with a richer morphology, such as Spanish and Portuguese, in different stages of acquisition. In this sense, it would be possible to observe the progression from default to more target forms. In addition, the inclusion of other variables of interest, such as language dominance and immersion/ non-immersion context should be included to test whether or not there is a distinct pattern of results. 


\section{References}

ABUTALEBI, J.; CAPPA, S.; PERANI, D. What can functional neuroimaging tell us about the bilingual brain? In: KROLL, J.F.; De GROOT, A.M.B. (Org.). Handbook of bilingualism: Psycholinguistic approaches. Oxford: Oxford University Press, 2005. p. 497-515.

BIBERAUER, T.; ROBERTS, I. Subjects, tense and verb movement in Germanic and Romance. Cambridge occasional Papers in Linguistics, Cambridge, v. 3, p. 24-43, 2008. Available at: <http://www.ling.cam.ac.uk/copil/papers/3-biberauer-roberts. pdf>. Retrieved on: 1 Sept. 2016.

BOND, K. et al. Examining sensitivity to agreement anomalies during online processing. In: RECONSIDERING SLA RESEARCH: DIMENSIONS AND DIRECTIONS. LANGUAGE RESEARCH FORUM (SLRF 2010), 2., 2010 Mariland. Proceedings.... Mariland: University of Maryland, United States, 2010.

CAMACHO, J. The Null Subject Parameter revisited. The evolution from null subject Spanish and Portuguese to Dominican Spanish and Brazilian Portuguese. 2012. Available at: <http://rci.rutgers.edu/ jcamacho/publications/Romania.pdf $>$. Retrieved on: 1 Sept. 2016.

CARNEIRO, M. M. Morfologia de flexão verbal no inglês como L2: uma abordagem a partir da Morfologia Distribuída. 2008. 149f. Thesis (Masters in Linguistic Studies) - Faculdade de Letras, Universidade Federal de Minas Gerais, Belo Horizonte, 2008. CLAHSEN, H.; FELSER, C. Grammatical processing in language learners. Applied Psycholinguistics, Cambridge, v. 27, p. 3-42, 2006. https://doi.org/10.1017/ S0142716406060024.

DOMÍNGUEZ, L. Knowledge of features in fossilized second language grammars. Second Language Research, Sage Journals, v. 23, n. 2, p. 243-260, 2007.

FITZMAURICE, G.; LAIRD, N.; WARE, J. Applied Longitudinal Analysis. Hoboken: John Wiley \& Sons, 2004.

FRANCESCHINA, F. Morphological or syntactic deficits in near-native speakers? An assessment of some current proposals. Second Language Research, Sage Journals, v. 17, p. 213-246, 2001.

HALLE, M.; MARANTZ, A. Distributed Morphology and the pieces of inflection. In: HALE, K.; KEYSER, S. J. (Org.). The View from Building 20: essays in linguistics in honor of Sylvain Bromberger. Cambridge: MIT Press, 1993. p. 111-176.

HARLEY, H.; NOYER, R. Distributed Morphology. Glot International, v. 4, n. 4, p. 3-9, 1999.

HARLEY, H.; RITTER, E. Person and number in pronouns: a feature-geometric analysis, Language, Washington, Linguistic Society of America, v. 78, n. 3, p. 482526, Sept. 2002. 
HAWKINS, R. Persistent selective fossilisation in second language acquisition and the optimal design of the language faculty. Essex Research Reports in Linguistics, University of Essex, v. 34, p. 75-90, 2000.

HAWKINS, R.; LISZKA, S. Locating the source of defective past tense marking in advanced L2 English speakers. In: VAN HOUT, R. et al. (Org.). The interface between syntax and lexicon in second language acquisition. Amsterdam: John Benjamins, 2003. p. 21-44. https://doi.org/10.1075/lald.30.03haw.

HAZNEDAR, B. Missing Surface Inflection in Adult and Child L2 Acquisition. In: GENERATIVE APPROACHES TO SECOND LANGUAGE ACQUISITION CONFERENCE (GASLA, 2002), $6^{\text {th }}$, 2002, Somerville. Proceedings..: Somerville: Cascadilla Proceedings Project, 2002. p. 140-149.

HERSCHENSOHN, J. Missing inflection in second language French: accidental infinitives and other verbal deficits. Second Language Research, Sage Journals, v. 17, n. 3, p. 273-305. 2001.

IONIN, T.; WEXLER, K. Why is 'is' easier than '-s'?: acquisition of Tense/ agreement morphology by child second language learners of English. Second Language Research, Sage Journals, v. 18, n. 2, p. 95-136, 2002.

JIANG, N. Morphological insensitivity in second language processing. Applied Psycholinguistics, Cambridge University Press, v. 25, p. 603-634, 2004.

JIANG, N. Selective integration of linguistic knowledge in adult second language learning. Language Learning, Wiley Online Library, v. 57, n. 1, p. 1-33, 2007.

JUFFS, A. Representation, processing and working memory in a second language. Transactions of the Philological Society, Wiley Online Library, v. 102, n. 2, p.199-225, 2004.

KATO, M.A. A evolução da noção de parâmetros. D.E.L.T.A. - Documentação de Estudos em Linguística Teórica e Aplicada, PUC-SP, v. 18, n. 2, p. 309-337, 2002. https:/ / doi.org/10.1590/S0102-44502002000200006.

LAKSHMANAN, U.; SEKINKER, L. Analyzing interlanguage: how do we know what learners know? Second Language Research, Sage Journals, v. 17, p. 393-420, 2001. LARDIERE, D. Case and tense in the 'fossilized' steady state. Second Language Research, Sage Journals, v. 14, n. 1, p. 1-26, 1998.

LEONARD, M. et al. Language proficiency modulates the recruitment of non-classical language areas in bilinguals. Plos One, San Francisco, CA, v. 6, n. 3, p. 1-10, 2011. https://doi.org/10.1371/journal.pone.0018240.

LILLO-MARTIN, D. et al. Bimodal bilingual cross-language influence in unexpected domains. In: COSTA, J.; CASTRO, A.; LOBO., M.; PRATAS, F. (Ed.). Language Acquisition and Development: Proceedings of GALA 2009. Newcastle upon Tyne: Cambridge Scholars Press, 2010. p. 264-275. 
LONG, M.H. Stabilization and fossilization in interlanguage development. In: LONG, M.H.; DOUGHTY, C. (Org.). Handbook of Second Language Acquisition. Malden, MA: Blackwell Pub., 2003. p. 487-535. https://doi. org/10.1002/9780470756492.ch16.

MaCSWAN, J. The architecture of the bilingual language faculty: evidence from intrasentential code switching. Bilingualism: Language and Cognition, Cambridge University Press, v. 3, n. 1, p. :37-54, 2000.

McCARTHY, C. Underspecification and default morphology in second language Spanish. In: BOSTON UNIVERSITY CONFERENCE, 29 $9^{\text {th }}, 2004$, Boston. Proceedings... Boston: University of Boston, 2004. Available at: <http://www. bu.edu/bucld/files/2011/05/29-MccarthyBUCLD2004.pdf>. Retrieved on: 1 Sept. 2016.

McCARTHY, C. What's missing from missing inflection?: features in L2 Spanish. MoGill Working Papers in Linguistics, Mc Gill University, Canada, v. 20, n. 2, p. 1-11, 2006.

McCARTHY, C. Morphological variability in the comprehension of agreement: An argument for representation over computation. Second Language Research, Sage Journals, v. 24, n. 4, p. 459-486, 2008.

MITCHELL, D. On-line methods in language processing: introduction and historical review. In: CARREIRAS, M; CLIFTON JR, C. (Org.). The on-line study of sentence comprehension: eyetracking, ERPs and beyond. New York: Psychology Press, 2004. p. 16-32.

MORRIS, J.; HOLCOMB, P. J. ERPs to violations of inflectional verb morphology. Cognitive Brain Research, Bethesda, v. 25, p. 963-981, 2005. https://doi.org/10.1016/j. cogbrainres.2005.09.021.

OSTERHOUT, L.; MOBLEY, L. A. Event-related brain potentials elicited by failure to agree. Journal of Memory and Language, Elsevier, v. 34, p. 739-773, 1995. https://doi.org/10.1006/jmla.1995.1033.

PEARLMUTTER, N. J.; GARNSEY, S. M.; BOCK, K. Agreement processes in sentence comprehension. Journal of Memory and Language, Elsevier, v. 41, p. 427-456, 1999. https://doi.org/10.1006/jmla.1999.2653.

PFAU, R. Grammar as processor: A Distributed Morphology account of spontaneous speech errors. Amsterdam: John Benjamins, 2009. https://doi.org/10.1075/la.137. PRÉVOST, P.; WHITE, L. Missing surface inflection or impairment in second language acquisition? Evidence from tense and agreement. Second Language Research, Sage Journals, v. 16, p.103-133, 2000.

RAPOSO, E. Teoria da gramática: a faculdade da linguagem. Lisboa: Editora Caminho, 1992. 
ROTHMAN, J. Sometimes they use it, sometimes they don't: an epistemological discussion of L2 morphological production and its use as a competence measurement. Applied Linguistics, Oxford Academic, v. 28, n. 4, p. 609-615, 2007. RULE, S.; MARSDEN, E. The acquisition of functional categories in early French L2 grammars: the use of finite and non-finite verbs in negative contexts. Second Language Research, Sage Journals, v. 22, n. 2, p.188-218, 2006.

SAGARRA, N.; HERSCHENSOHN, J. Proficiency and animacy effects on L2 gender agreement processes during comprehension. Language Learning, Wiley Online Library, v. 61, n. 1, p. 80-116, 2011.

SATO, M.; FELSER, C. Sensitivity to semantic and morphosyntactic violations in L2 sentence processing: Evidence from speeded grammaticality judgments. Essex: University of Essex, 2007.

SELINKER, L. Interlanguage. International Review of Applied Linguistics in Language Teaching, De Gruyter, v. 10, p. 209-231, 1972.

SLABAKOVA, R. What is easy and what is hard to acquire in a second language? In: GENERATIVE APPROACHES TO SECOND LANGUAGE ACQUISITION CONFERENCE, $10^{\text {th }}$, 2009, Somervillem. Proceedings... Somervillem: Cascadilla Proceedings Project, 2009. p. 280-294.

SORACE, A. Introduction: Syntactic optionality in nonnative grammars. Second Language Research, Sage Journals, v. 16, p. 93-102, 2000.

TOWELL, R. Representational modularity and second language acquisition research. Transactions of the Philological Society, Wiley Online Library, v. 102, n. 2, p. 281-305, 2004.

TRENKIC, D. Variability in L2 article production: beyond the representational deficit vs. processing constraints debate. Second Language Research, Sage Journals, v. 23, n. 3, p. 289-327, 2007.

WHITE, L. Fossilization in steady state L2 grammars: Persistent problems with inflectional morphology. Bilingualism: Language and Cognition, Cambridge Universtity Press, v. 6, n. 2, p.129-141, 2003.

WHITE, L. et al. Gender and number agreement in nonnative Spanish. Applied Psycholinguistics, Cambridge University Press, v. 25, p. 105-133, 2004.

XAVIER, G. R. Aquisição do PB como L2: o sujeito nulo. Revista da ABRALIN, Abralin, v. 7, n. 1, p. 95-127, jan./jun. 2008.

Data de submissão: 12/09/2016. Data de aprovação: 30/01/2017. 
